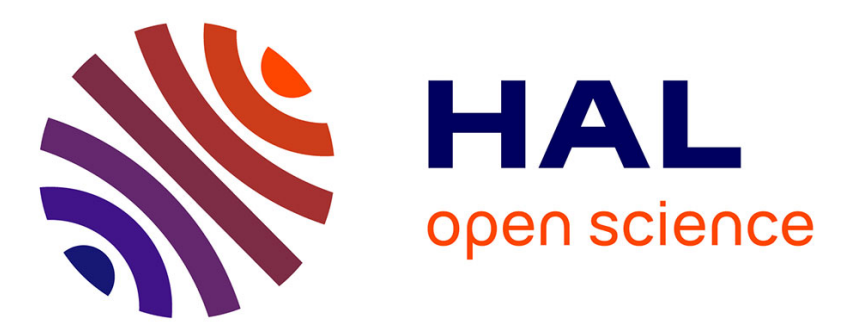

\title{
The French politics of retrenchment (2007-2012): Institutions and blame avoidance strategies
}

\author{
Philippe Bezes, Patrick Le Lidec
}

\section{To cite this version:}

Philippe Bezes, Patrick Le Lidec. The French politics of retrenchment (2007-2012): Institutions and blame avoidance strategies. International Review of Administrative Sciences, 2015, 81 (3), pp.523 547. 10.1177/0020852315576712 . hal-02180051

\section{HAL Id: hal-02180051 \\ https://hal-sciencespo.archives-ouvertes.fr/hal-02180051}

Submitted on 11 Jul 2019

HAL is a multi-disciplinary open access archive for the deposit and dissemination of scientific research documents, whether they are published or not. The documents may come from teaching and research institutions in France or abroad, or from public or private research centers.
L'archive ouverte pluridisciplinaire HAL, est destinée au dépôt et à la diffusion de documents scientifiques de niveau recherche, publiés ou non, émanant des établissements d'enseignement et de recherche français ou étrangers, des laboratoires publics ou privés. 


\title{
The French politics of \\ retrenchment (2007-2012): \\ Institutions and blame avoidance \\ strategies
}

\section{Philippe Bezes}

Centre d'E' tudes et de Recherches de Sciences

Administratives et Politiques (CERSA), France

\section{Patrick Le Lidec}

Sciences Po, France

\begin{abstract}
While the semi-presidential French regime and the reinforcement of 'presidentializa-tion' under Nicolas Sarkozy have often been associated with the idea of disruptive and heroic changes, France's post-crisis budgetary policy appeared strongly embedded in the previous commitments made by President Sarkozy and relied largely on measures of a gradual and low-profile nature without significant U-turns. In order to explain this result, the article emphasizes the effects of French institutions on government capabilities and on the potential allocation of blame and the related political strategies connected with the electoral cycle and timing. In addition, it also explores the specific characteristics of the French national crisis and its perceptions by top bureaucrats, as well as the nature of the external macro-constraints that influenced French budgetary policy, whether originating with markets, international organizations or the European Union.
\end{abstract}

\section{Points for practitioners}

This article emphasizes the importance of institutions and political strategies in cutback management. The main argument is that budget reduction policies are embedded in pol-itical and electoral constraints that strongly affect their design and choices. The article provides many empirical elements about the specific characteristics of the French national crisis and how French governments reacted to the 2008 crisis. It puts emphasis on the specificities of French political institutions and the strong exposure to blame. The French political strategies of blame avoidance are described between 2008 and 2012, as well as the nature of the external macro-constraints that influenced French 
budgetary policy, whether originating with markets, international organizations or the European Union.

\section{Keywords}

Blame avoidance, fiscal adjustment, fiscal policy instruments, France, retrenchment, semi-presidential regime

\section{Introduction}

Over the last decades, democracies have found themselves in a dilemma. On the spending side, past commitments take up an ever-growing proportion of budgets, generating strong inheritance or legacy effects (Pierson, 2001). This freezing of historical patterns of government spending leads to 'fiscal sclerosis', combined with a decline in fiscal democracy characterized by two phenomena (Streeck and Mertens, 2013: 27): the level of mandatory spending increases to the detriment of discretionary spending; and 'state activities are increasingly less responsive to changing interests among the citizenry' (Streeck and Mertens, 2013: 27). Moreover, growing fiscal competition between countries results in a freezing of revenues, and the constant rise in debt that ensues impacts negatively on the legitimacy of governments. The 2008 financial crisis took place within this context and exacerbated the problems because it required governments to find leeway to stimulate their economies, while, at the same time, further reducing revenues, thereby making more cuts necessary at the risk of triggering a recessionary spiral.

From this perspective, a detailed study of the French response to the 2008 crisis is interesting, for two reasons. The first is that the French budget is specifically rigidified. The crisis occurred against a background of 40 years of deterioration in the public finances, with several factors explaining the increasing rigidity of the budget: civil service salaries; operational expenses and welfare spending; and the increasing proportion of the budget allocated to debt servicing. This has led to a 'great petrification' (Baumgartner et al., 2009; Siné, 2006). National debt grew eighteenfold between 1978 and 2007, while it rose as a proportion of gross domestic product (GDP) from $21.1 \%$ in 1978 to $40 \%$ in 1992, reaching $64 \%$ in December 2007 (Champsaur and Cotis, 2010). In addition, since the early 2000s, tougher fiscal competition prompted governments to reduce tax rates, reductions assessed at $4.3 \%$ of GDP between 2000 and mid-2012 (Cac, 2014). All this hints at the powerful vested interests behind public spending in France, which have managed to obtain benefits from tax policies (specifically from tax loopholes), while other groups find themselves dealing with a state that is increasingly less responsive to their interests. This growing difficulty in meeting new demands has made it increasingly hard for politicians to satisfy their electoral clienteles: since 1978, France has experienced a continuous cycle of political swings at each general election, with only one exception in 2007 (when Sarkozy managed to mark himself out 
from his predecessor, despite being of the same party, by campaigning on the theme of a clean break).

The second reason why the French case makes an interesting study is that the semi-presidential regime established under the Fifth Republic is generally seen as one with a strong executive. Leaders are seen to have extensive decision-making capacity, arising from the exceptional legitimacy conferred by the election of the president by direct universal suffrage and from instruments of rationalized parliamentarianism that supposedly allow him to impose his will on Parliament. Nicolas Sarkozy's victory stood out in two ways: it was incontestable and gave the president a very strong mandate to govern (he was elected by a wide majority of $53 \%$ of votes, with very high voter turnout $(83.97 \%))$; and it was accompanied by radical reforming rhetoric and a liberal platform.

These two elements result in a paradox. While the French regime and the reinforcement of 'presidentialization' under Sarkozy have been associated with the idea of disruptive and 'heroic' changes, France's post-crisis budgetary policy appeared strongly embedded in the frozen historical patterns of government spending, but also in the initial commitments made by Sarkozy vis-a-vis his clienteles immediately following his election in 2007. The purpose of this article is to explain why French responses to the financial crisis have not opened a window of opportunity for setting fundamentally new priorities and sustainable long-term solutions that would alter existing policies and change the distribution of benefits between interest groups. In explaining the formulation of France's post-2008 policy of retrenchment, we will draw on theories that analyse the politics of retrenchment in welfare states (Pierson, 1994) and fiscal consolidation by showing how institutions, blame-avoidance factors (Hood, 2002; Weaver, 1986) and the electoral cycle and timing play an important role in framing the rationales of political leaders. These political rationales will be balanced by the national characteristics of the crisis and the way in which it is perceived by politicians and senior bureaucrats, as well as by the nature of the external macro-constraints that influenced French budgetary policy, whether originating with markets, international organizations or the European Union (EU) (Kickert, 2012).

We will first develop our theoretical framework by describing the characteristics of France's institutions and their influence on blame-avoidance strategies. We will then provide a detailed characterization of the 2008 fiscal crisis in France and the resulting fiscal policy by dividing the years 2007-2012 into four periods. In the last section, we will address the interwoven factors (economic, political, external) that may explain the governance of France's fiscal crisis, with a particular focus on the importance of the political dimension.

Our exploration of France's politics of retrenchment over the years 2007-2012 draws on several sources. We began by building a comprehensive chronology of the many fiscal and taxation measures adopted by the Fillon government from 2007 to 2012. From public documents produced during the process and from press releases, we systematically analysed these measures in the light of our theoretical framework. We also conducted several in-depth taped interviews with individuals from 
the various executive and ministerial organizations engaged in these policies (presidency, prime minister, Budget Directorate, Treasury Directorate, State Modernizing Unit).

\section{Our theoretical argument: Blame avoidance, interest groups and retrenchment}

How did the French government react to the 2008 crisis and how were both the recovery programme and the politics of retrenchment constructed following the crisis? Our argument is that fiscal responses were shaped not so much by the quest for a 'viable' and 'correct' economic and budgetary diagnosis of the crisis, or by the aim of adopting drastic remedies, but, above all, by political strategies geared towards electoral constraints, interest groups and constituencies, and blame-avoidance objectives. We suggest that France's institutions are particularly conducive to such outcomes.

\section{France's semi-presidential regime, the management of the public finances and blame avoidance: A two-edged sword}

France's Fifth Republic, often referred to as a semi-presidential regime (Duverger, 1980; Elgie, 1999), has traditionally been seen as characterized by a set of institutions that provide strong decision-making capacities. Although the Constitution of 4 October 1958 established a parliamentary system, both institutional practice and constitutional reforms have increasingly reinforced the president's pre-eminence over the prime minister, with the president being elected by popular vote and the Chambers enjoying only limited legislative powers (Brouard et al., 2009; Elgie, 2013). The constitutional reform of 2000 reinforced the presidentialization of the regime by bringing the presidential and parliamentary terms into alignment and thus reducing the probability of a government split ('cohabitation') between a president and prime minister from opposite parties. Nicolas Sarkozy accentuated this 'presidentialization', which earned him the sobriquet of 'hyper-president'. He was a clear election winner, standing on the platform of a break with the welfare state model of the past and a commitment to more liberal and business-friendly policies, along with tax cuts.

As widely acknowledged in the comparative literature on budget policies (Schick, 1991; Wildavsky, 1975), formal institutions do play a role in the formulation of retrenchment policies. In the French case, a dominant view has been that it is easy to legislate for reform and to act on fiscal matters under France's Fifth Republic system because of the power it grants to the executive. As a result, ministers in the Finance and Budget Ministries, as well as top bureaucrats in the Treasury and Budget Division, have played a central role in the core executive through their command of financial coordination (Hayward and Wright, 2002: 164-187). Moreover, France's semi-presidential regime has often been associated with the concentration of power, strong administrative capacities - with top 
bureaucrats protecting the 'general interest' - and 'heroic politics' (François, 1998). We suggest that this view is misleading, at least for the policies of retrenchment affecting the many constituencies and interest groups attached to welfare state, and economic and business policies. As advanced by Pierson (1994: 70), 'the theoretical case for expecting centralized systems to be more successful is suspect' since 'the greater centralization of political institutions is a two-edged sword: centralized government concentrates power but it concentrates accountability ... the greater institutional control must be weighed against the greater likelihood that it would be blamed for unwanted reforms'. The reduction of the presidential term to five years has further increased the president's exposure to blame. As the literature on welfare state retrenchment suggests (Starke, 2006), when determining 'governmental capacity for loss imposition' (Pal and Weaver, 2003: 294), the 'concentration of power effects' must be empirically weighed against the 'concentration of accountability effect'. The more institutional or partisan control over government policy becomes unified, the easier it gets for individuals to make judgements of political responsibility. Political institutions with a high concentration of power will also concentrate blame, while fragmented systems will have greater potential to 'share' or 'shift the blame' but also to build coalitions. In the French context, the likelihood of the president being blamed is high for two primary reasons.

First, the fact that the president is directly elected makes him/her an electorally powerful figure for the majority since 'members of the legislature will not cross the president because the president is the most valuable vote getter that political parties possess' (Huber, 1996: 30). This mechanism has been further reinforced with the constitutional reform of 2000 and the primacy of the presidential elections, which strengthen the perception that the president is the person really in charge.

Second, while power largely proceeds from the president and his/her election, the president is not accountable to Parliament whereas, by contrast, the government is accountable both to Parliament and to the president. This means that the government and prime minister are primarily subordinate to the president, and may be used as potential scapegoats (Grossman, 2009: 44).

This concentration of political power increases political accountability and implies a high risk of political loss in implementing a policy of retrenchment (Hood, 2002; Pierson, 1994; Weaver, 1986). In the absence of mechanisms of collective responsibility (like those found in parliamentary regimes and in coalition governments), the political cost of large-scale reforms is particularly high: minority parties that have no share in power are encouraged to take up populist opposition strategies designed to win them the next elections, in a constant seesaw process. Opposing the reforms introduced by the government in place is a passport to power at the next election, though at the risk of sparking rapid disenchantment. In addition, it prompts politicians to be particularly watchful of their electoral support, to favour incremental reforms (Pisani-Ferry, 2014), to pay particular attention to interest groups potentially affected by cutbacks and to protect their political constituencies from policies of retrenchment. With this perspective in mind, we explore the idea that retrenchment policies depend largely on their 'political viability' 
(Hall, 1989: 374-375), that is, the political and electoral implications of economic or budgetary solutions and cutbacks. The consequence of the strength of the political executive in France is therefore more to allow the president to make choices based on political considerations than to impose drastic reforms.

\section{Perceptions and anticipations of the nature of the crisis and of 'external' constraints}

Two further points need to be made in characterizing the political and administrative reasoning at work. The choice of solutions for resolving the crisis and the anticipation of the associated risks of credit and blame depend, on the one hand, on the perception of the nature and intensity of the economic crisis and, on the other hand, on the perception of the constraints weighing on the state in question. These dimensions give a large role to key senior civil servants serving in the Budget Directorate, in the Treasury Department and in the president's and prime minister's cabinets. Of course, their interpretations and solutions may be filtered and selected by politicians and will depend on the institutional relationship between politicians and bureaucrats.

As suggested by many authors (Blyth, 2002: 10; Hall, 1989), the interests at stake in a crisis and the interpretations of that crisis are far from unambiguous. Several scholars emphasize the role played by ideational legacies or economic traditions, such as 'statist liberalism' (Vail, 2014) or, for the French case, 'post-dirigisme' (Clift, 2012b), in the framing of economic and budgetary responses to crises. Our approach is slightly different because the mechanisms through which these intellectual frameworks operate often remain insufficiently precise: these supposed legacies correspond to national stereotypes (the strength of Keynesianism in France) of questionable validity, and are contradicted by other studies that emphasize the presence of a neoliberal trend in French affairs. Following Starke's (2006: 113) suggestions, we prefer not to presuppose the existence of frameworks but to show how budgetary choices were politically, administratively and economically constructed and how the actors involved understood the crisis and its various dimensions. We thus focus on bounded rationalities and the way in which they have been constructed (Cox, 2001), a mix of economic diagnoses, budgetary constraints and political strategies.

The second important constraint affecting government decisions is the perceptions of the constraints - wrongly called 'external' - that characterize the interdependencies within which Eurozone economies and states are required to operate, as well as the expectation of potential leeway in tackling these constraints. In the case of the 2008 crisis, the constraints are obviously linked with the new European treaties (Clift and Ryner, 2014: 141-143). Beyond the very high exposure of French banks to risks from the Southern European countries, which constitute a further incentive for France to argue for a strengthening of solidarity mechanisms, it is the integration of the European economies that leads to the perception of the situation as one of 'systemic risk', which makes it acceptable for French leaders to surrender 
sovereignty to a degree that they would consider inconceivable in other circumstances. Leaders' perceptions of the attitude of the financial markets are also crucial because - at certain moments - the solutions they choose constitute, above all, signals for the markets. This concern for market credibility has been central and encompasses issues like the perception of France's reputation and the confidence of financial markets, trends in borrowing costs, or the maintenance of the country's AAA credit rating by the bond-rating agencies (Clift, 2013).

\section{Tensions and contradictions in France's fiscal consolidation policy: When budget constraints meet politics}

When examining how the French government responded to the fiscal crisis, it is important to consider a longer period, beginning in May 2007. Budgetary policy and cutbacks are constrained by factors inherited from previous political commitments and fiscal and tax policies (Schick, 1991). Since all decisions took place during Sarkozy's presidential term, the 'politics of cutback budgeting' were severely constrained by the electoral agenda. Emphasizing the strength of blame-avoidance factors, but also the bounded structure of decisions on budgetary and economic choices by French senior officials, we have divided the process into four sequences: the initial decisions of 2007; the 2008 crisis; and two successive responses between late 2008 and 2010.

\section{Before the crisis: An ambivalent balance between spending cuts and tax cuts (May 2007-September 2008)}

In France, the crisis occurred more than a year after the new presidency had launched its new policies. Hence, the idea of spending reviews and cutbacks was not a reaction to the 2008 crisis, but was formulated in the mid-2000s, introduced in Nicolas Sarkozy's 2007 electoral platform and implemented soon after his election. The initial choices were based on the beliefs, founded on the Camdessus (2004) and Pébereau (2005) reports and supported by the president's entourage, that the direction of France's public spending was not sustainable. The 2008 crisis occurred more than a year after the initial decisions. Several of the devices employed after the 2008 and 2010 crises were conceived before then and were reinforced rather than undermined by those events. However, austerity was far from the sole factor in the formulation of the government's budget and economic policy from 2007. Large tax cuts were offered to reward the winning candidate's backers (the rich) and to support interest groups. The initial policy mix was, then, ambiguous and paradoxical.

On the one hand, in July 2007, the president and his team had launched a General Public Policy Review (RGPP). During his campaign, Sarkozy had advocated a global financial plan dominated by cuts in public expenditure, while promising a reduction in the tax burden. Ministries were thus asked to schedule spending reductions but also to reshape their own roles and to consider alternative strategies for delivering their public policies (Bezes, 2010). Organizational decisions 


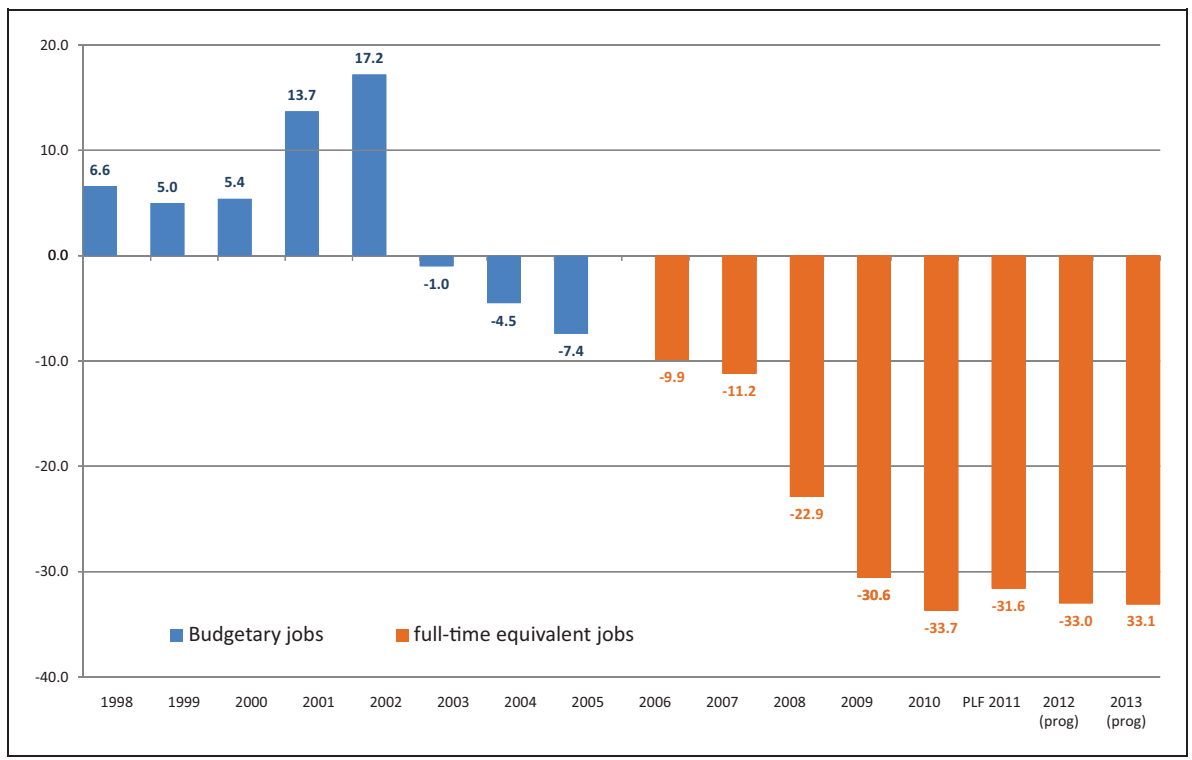

Figure I. Public staff reduction in France in the 2000 s.

Source: Direction générale du Trésor (2010).

focused predominantly on: abolishing departments; eradicating overlaps; increasing government efficiency through eliminations, simplifications, mergers, lean management, synergies, automation, better management and better command and control intended to generate budget savings; achieve cutbacks; and enhance productivity and efficiency.

The Fillon government had also strengthened budgetary dominance by creating an enlarged Ministry for Budgeting, Public Accounts and the Civil Service to enforce a systematic control of central and local governments, as well as on social security. The RGPP included initiatives to restrict state expenditure. First, the 2008 Budget Bill capped state spending increases to no more than projected inflation ('zero volume') for the entire mandate through to 2012. A second important measure was a restructuring process to reduce the number of civil servants, achieved by the non-replacement of one in two retiring state employees. The 2008 Finance Bill set a target of eliminating the equivalent of 22,800 full-time civil service posts (see Figure 1). ${ }^{1}$ In order to push through this policy of non-replacement, the Fillon government undertook to allocate $50 \%$ of the resulting savings to the remaining staff in the form of 'wage compensation' intended to offset the negative effects of the reforms. According to the Budget Directorate, the total amount finally saved through the RGPP between 2007 and 2012 was $€ 11.9$ billion (IGA et al., 2012), of which $€ 3.6$ billion came from the reduction in personnel costs.

During this pre-crisis period, one final initiative came onto the agenda: a multiannual public finance policy underpinned by a multiannual budget based on the 
RGPP. Inspired by the Budget Directorate, the multiannual public finance policy received constitutional ratification through the revision passed by Parliament on 21 July 2008. The first multiannual budget set the financial course for all civil service departments (central government, social security and local authorities) for the period 2009-2012, along with the principles of governance required to steer this course.

On the other hand, measures taken in July 2007 also reveal a political payback agenda running counter to the objective of restoring the sustainability of the public finances. The cost of the French fiscal package of 2007, called the loi TEPA, was assessed in 2008 at $€ 9$ billion. First, the loi TEPA included an exemption from income tax and payroll taxes on overtime. Second, it contained a number of measures that benefited the right-wing electorate. 'Inheritance tax' was eliminated for $95 \%$ of direct inheritance, and donations to children and grandchildren were encouraged by tax exemptions. In addition, total income tax and local property taxes assessed on the main residence, as well as wealth taxes and corporate surtaxes, had already been limited by the application of the 'bouclier fiscal', or tax shield, which limited the maximum amount of tax payable on income to $50 \%$. Moreover, up to $€ 50,000$ invested in equity for small and medium enterprises was made deductible from the so-called solidarity wealth tax (ISF). Tax relief on the main residence in the calculation of ISF was increased to $30 \%$. These electiondriven decisions drew criticism from top bureaucrats in the Budget Ministry and Treasury Department, who saw that they would contribute significantly to deficit and debt levels in circumstances where a number of worrying signals from the US were already pointing to a deterioration in economic conditions. Indeed, the macroeconomic background provided in the 2008 finance White Paper, presented by the Treasury Department on 26 September 2007, drew immediate attention to four major risks in the US: the sharp fall in residential investment in the US; the sudden increase in mortgage defaults; the rise in stock market volatility; and the abrupt drop in global demand and trade. The negative impact of these risks on France's situation was mentioned: escalating tensions in the credit markets, affecting global economic activity; tighter financing conditions; the collapse of asset values; and a fall in investment and consumption. France would face a $0.5 \%$ drop in growth in 2008.

Even before the crisis, therefore, Sarkozy's policy seems somewhat unbalanced and likely to exacerbate the debt, since the cost of the tax cuts introduced by the Ioi TEPA was far from covered by the spending decisions taken under the RGPP review.

\section{Enter the 2008 crisis in France: A parenthesis of stimulus}

The financial crisis began 15 months after Nicolas Sarkozy's election. From 2008, the total government deficit increased rapidly, reaching $7.5 \%$ of GDP in 2009 . The crisis ended the country's ability to contain the rise in public debt, which had stabilized over the period 2004-2007 (at 64\% of GDP), a stability at least partially 
Table I. Main budgetary and economic figures for France

\begin{tabular}{lllllll}
\hline & 2006 & 2007 & 2008 & 2009 & 2010 & 2011 \\
\hline GDP per capita (€) & 28,400 & 29,600 & 30,100 & 29,200 & 29,900 & 30,600 \\
Real GDP growth rate (\%) & 2.5 & 2.3 & -0.1 & -3.1 & 1.7 & 1.7 \\
$\begin{array}{l}\text { General government } \\
\quad \text { deficit/surplus (\% of GDP) }\end{array}$ & -2.3 & -2.7 & -3.3 & -7.5 & -7.1 & -5.2 \\
$\begin{array}{l}\text { General government } \\
\quad \text { gross debt (\% of GDP) }\end{array}$ & 63.7 & 64.2 & 68.2 & 79.2 & 82.3 & 85.8 \\
$\begin{array}{l}\text { Inflation (HICP) } \\
\text { Unemployment rate (ILO) }\end{array}$ & 1.9 & 1.6 & 3.2 & 0.1 & 1.7 & 2.3 \\
\hline
\end{tabular}

Source: Eurostat.

attributable to creative accounting. Public debt rose by 22 percentage points over the period in question (2007-2011), that is, five times faster than over the previous 15 years (Champsaur and Cotis, 2010; see also Table 1).

The crisis of 2008 caught the executive on the back foot. It embarked on a policy of budgetary expansion to absorb the shock caused by the collapse of Lehman Brothers. This ushered in an ambiguous and very short-lived period of stimulus, culminating in the international G20 summit in London in April 2009. Here, our enquiry leads us to challenge the interpretation that the French response to the crisis reflected the existence of state traditions of economic policy (the 'statist liberal tradition' (Vail, 2014) or 'post-dirigisme' (Clift, 2012b)) and the strength of Keynesian ideas at the Ministry of Economics and Finance (Vail, 2014: 71). Instead, our investigation identifies a dividing line, within the executive itself, between partisans and adversaries of Keynesian stimulus policy, which resulted in the defeat of the former. While the president's special adviser, Henri Guaino, advocated the need for a massive (€100 billion) stimulus plan, the main players then involved in economic and budgetary decision-making - whether the Elysée's deputy secretary-general responsible for economic policy, the head of the Treasury, the Budget director or different advisers to the president, prime minister and minister of economics and finance on economic and budgetary matters - shared uniform orthodox liberal views. With a background in the Treasury and Budget departments, and, in some cases, a spell in the financial sector, they were highly critical of France's last Keynesian stimulus plan, dating from the early 1980s, at a time when the country's economic competitiveness had been in decline since the early 2000s.

The onset of the 2008 crisis did not greatly alter their view of the handicaps affecting the French economy (a continuously declining trade balance ${ }^{2}$ and deterioration in the public finances). ${ }^{3}$ These senior officials were critical of the deliberately optimistic bias traditionally apparent in France's growth forecasts, and of the interference of political considerations in the construction of growth projections, resulting in systematic disparities between budget forecasts and 
outcomes. They were (privately) critical of politicians, whom they saw as too concerned to avoid the blame inherent in consolidation policies. They were largely in favour of sharp cuts in expenditure on civil service personnel and on transfers, and very mistrustful of a Keynesian doctrine seen as a constant game of catch-up, dictated by electoral strategies of 'credit claiming'. These individuals tried to contain the temptation of a Keynesian response on the assumption that there could be no consumption-based national solution in a country that had accumulated a record balance-of-trade deficit, which would be further exacerbated by a policy of reflation. A compromise between the need for stimulus and continued austerity led to the adoption of a policy of 'Ri-lance', to employ a term coined by Minister of Economics and Finance Christine Lagarde, a combination of two words -'rigueur' (rigor) and 'relance' (stimulus) - referred to the 'subtle' mix of cutback measures and stimulus policies. ${ }^{4}$

\section{The new balance of power in response to the crisis: Framing the recovery plan, course adjustments and sending signals to markets (September 2008- February 2010)}

In response to the shock caused by the Lehman Brothers collapse and the interbank crisis, France's leaders drew up a recovery plan that was essentially national. However, it was repackaged as an element of a European recovery plan presented at the G20 summit in London on 2 April 2009.

A recovery plan targeted more at investment than consumption: A patriotic strategy in support of an uncompetitive economy. The recovery plan adopted by the French government sought, first, to respond to the need not to further undermine a domestic economic and budgetary situation seen as deeply compromised. By setting the level of the national contribution at $€ 26$ billion, the government chose to position itself at precisely $1.3 \%$ of GDP, the midpoint of the range set for Europe by the heads of state and government. If we take out the cash-flow measures, which were not included in the data for other countries, the French plan represented only some $1.1 \%$ of GDP, placing it second from bottom of the major developed nations.

However, it differed from many recovery plans that sought to stimulate consumption. Indeed, as one of the players involved in the process explained: 'regarding the stimulus, we pretended to be scraping $1.2 \%$ of GDP, and then we made a cash advance, in other words we brought forward investments that were already scheduled'. The French approach was characterized by the scale of the effort made to boost corporate cash flows and public and private investment. Out of a total initial estimated amount of $€ 26$ billion: $€ 11.6$ billion were allocated to measures to improve company cash flows, notably, through tax measures in the budget; $€ 10.5$ billion were allocated to public investment, divided between the state ( $€ 4$ billion), public companies ( $€ 4$ billion) and local authorities ( $€ 2.5$ billion), though this was not, strictly speaking, new or additional investment, merely a bringing forward of public investment measures already scheduled for the subsequent years; and $€ 2$ 
billion were allocated to two sectors particularly exposed to the effects of the economic crisis - housing (support for local employment) and the car industry (with targeted measures in favour of low-powered vehicles, a market dominated by French manufacturers). The cost of these exceptional investment measures was offset by the use of a national loan combined with a concomitant reduction in operating expenses. These choices fit with an interpretation in terms of liberal patriotism (Clift, 2012a) insofar as they reflect a desire to support key sectors of the French economy exposed to little or no international competition. Conversely, they demonstrate that - by contrast with the claim made by Vail (2014) - there was no wish to implement a Keynesian policy of stimulus through consumption.

The challenge for the executive was to find a way to reconcile this temporary stimulus with the continuing goal of reducing structural spending, as contained in the 2009-2011 multiannual programmes. The Budget Ministry's objective was to ensure that the exceptional investment drive did not deflect ministries from their targets for reducing growth in their operating expenses, and to prevent the countercyclical measures adopted from undermining the credibility of the strategy to bring about sounder public finances and the new cognitive frame that the Budget Ministry was seeking to impose. A special budget was created to fund this plan: it would ring-fence the exceptional allocations from ordinary government spending, which should then be traceable throughout the whole implementation chain. The aim was to avoid these allocations continuing beyond the term of the recovery plan. An ad hoc cross-cutting 'Economic Recovery Plan' was created by the Corrective Finance Bill of 4 February 2009, slated to finish at the end of financial year 2010. Far as it was from Keynesian standards, the short-lived 'Ri-lance' parenthesis closed quickly anyway with the onset of the sovereign debt crisis.

Consolidation measures taken in response to the crisis. By contrast, a first package of measures to reduce the rate of growth in public spending was introduced with the passing of the first Public Finance Planning Act in February 2009 (for the Period 2009-2012). To slow the growth of public spending, a zero-volume rule (excluding the recovery plan) for 2009, 2010 and 2011 was set for state expenditure, with the aim of extending it to the whole public sphere. The annual rate of increase in spending by the state, state operators and primary social security bodies was restricted to $1.1 \%$. The maximum rate of increase in health care and social security expenses was set at $3.3 \%$. With regard to local authorities, the government was constitutionally precluded from applying a spending cap. Faced with this constitutional obstacle, it applied a zero-volume rule to central government allocations to local authorities (which did not prevent them from offsetting the fall in state support by increasing local taxes).

Sending signals to markets: Making working people pay for the recovery while sparing pensioners. In addition, in circumstances marked by an anticipated increase in the public deficit and a growing risk of interest rate rises, the government chose to send a signal to the markets in order to give credibility to the president's undertaking to 
move expenditure trends in the right direction by announcing the decision to reform the pensions system, with the stated aim of balancing the pension books by 2018 .

The equilibrium on which the pension reform was based was very comparable with that underpinning the recovery plan, with the principle of balancing countercyclical investment by planned cuts in operating expenses. The pension reform was forecast to generate a gain of $€ 16$ billion in 2016 and to prevent a $€ 49$ billion rise in debt between 2012 and 2016. Nevertheless, it was seen by many observers as a convenient short-run strategy to buy time. The strategic character of this reform was particularly transparent in view of the government's decision that the pension reserve fund, which was supposed to be used only after 2020, would be gradually depleted from 2011 in order to cushion the deficit in the system over the period of implementation, and because the whole plan was based on deliberately optimistic forecasts by the Conseil d'orientation des retraites (COR). The Cour des Comptes (2013) exposed the incapacity of the reform to meet the pension system's funding challenges in the context of an ageing population. Despite the high level of French pensions on international comparisons (OECD, 2013), ${ }^{5}$ the pension reform represented a trade-off to the advantage of ageing and retired people (who voted massively for Sarkozy), and to the detriment of young people and people in employment.

\section{A systematic but low-profile policy of retrenchment under electoral constraints (March 2010-May 2012)}

This final period was characterized by an intensification in the tensions, not to say the contradictions, between deteriorating economic conditions that seemed to call for the adoption of drastic measures, and the move into the end phase of the electoral cycle (in 2012), which conversely offered an incentive to defer their adoption to a post-election time frame. Four types of measures and strategies were adopted over this period.

Holding down spending by applying a zero-value standard. The first measure was to adopt a new Corrective Finance Bill for the period 2011-2014 and to introduce a new rule into the 2011 Budget Bill to stabilize all public expenditure at 'zero value', excluding interest on debt and pension spending over the period 2011-2013. This so-called 'zero-value rule' was a way to achieve the 'zero real-terms expenditure' ('zero volume') target for the entire national budget. It enabled the government to counter the inevitable upward trend in these costs for that period, which would, in fact, have absorbed virtually all the slack that would have emerged if total public spending grew in line with the expected rate of inflation $(+1.5 \%$ in $2011 ;+1.75 \%$ in 2012/2013). Allowing for the steady growth in the cost of debt and pensions, the application of this strict principle meant reducing the state's operating expenditure by $10 \%$ in three years, with a reduction of $5 \%$ in 2011 , a target to be achieved essentially through the savings generated by the RGPP. One significant measure affecting the civil service wage bill was a freeze on the point value of civil service 
pay from 2010. The resulting net fall in the purchasing power of public servants (relative to inflation) came on top of the rise in their pension contributions discussed earlier, and had the effect of making measures affecting civil servants the primary variable used in adjusting the budget. All these actions reduced the annual rate of growth in the volume of public spending by an average of $0.8 \%$ over the period 2011-2013. Nonetheless, this overall target varied in its application between the different components of the public sector.

Sharing the burden: Extending restraint to all public bodies. With the adoption of the three-year budget for 2011-2013, spending cuts were extended to other public bodies, such as agencies, where costs had continued to grow rapidly. To this end, the government organized two 'national deficit conferences' on 28 January and 20 May 2010, bringing together everyone involved in public spending.

A prime ministerial circular on 26 March 2010 also introduced strategic 'guidance' for all 'state operators', for example, all public organizations at arm's length from central administrations, including agencies, établissements publics, universities and so on. This strategic guidance process extended the Loi Organique relative aux Lois de Finances (LOLF) framework and entailed the introduction of clear targets through performance contracts for each agency. The reform also imposed a $10 \%$ reduction in operating costs over a three-year period (20112013) and a reduction in personnel costs of $1.5 \%$ per year.

As regards social security, the application of the spending rule to health-care expenditure (Objectif National de Dépenses d'Assurance Maladie, ONDAM) was intensified. The limit on national health-care spending, defined in terms of nominal growth rates, was reduced from $3.3 \%$ in 2010 to $2.8 \%$ for the years 2011 to $2014 .^{6}$

Two types of targeted savings measures were introduced to slow the rate of growth in local authority spending. The first was the application of a zero-value rule to financial transfers from central government to local authorities for 20112013. The option of a sharp cut of several billion euros in central government allocations proposed to the president was postponed until after the 2012 presidential elections. The second measure was the replacement of the business tax (the rate of which was set by local authorities) by a new tax on corporate added value (CVAE) (with a maximum national rate set by Parliament) in order to slow down the rate of growth in local authority revenues (Le Lidec, 2011).

Increasing tax yields while avoiding the blame: Disguised increases and 'virtuous taxes'. With regard to decisions on the revenue side, the strategy was also to use low-profile instruments (Bezes, 2007) and obfuscation strategies (Lindbom, 2007; Pierson, 1994), mainly through disguised increases in certain taxes and numerous measures to eliminate and rationalize fiscal spending. Due to electoral constraints, the patchwork of revenue measures was rather inconsistent, running counter to the stated goal of clarifying and simplifying the French tax system. In response to the Court of Accounts recommendation for a $€ 10$ billion cut in the total cost of fiscal expenditure, matched by the same amount from corporate tax shelters from 2011 onwards 
(Cour des comptes, 2010), the government applied a general cheese-paring strategy in these areas. The public finance planning bill for the period 2011-2014 provided for a minimum yield of $€ 11$ billion in 2011, primarily relying on measures to increase compulsory contributions and on the elimination of fiscal spending and corporate tax shelters. The report appended to the finance White Paper for 2012 provided for the elimination of $€ 5.2$ billion of tax shelters in 2011 followed by a further reduction of $€ 1.6$ billion (Cour des comptes, 2012: 104). In itself, the technique employed - prioritizing the elimination of tax shelters rather than increasing tax rates - reflects the efforts by the president to remain faithful, if not to the spirit of his programme, at least to the letter of his electoral undertakings, having promised in 2007 not to increase tax rates.

Nonetheless, there were two kinds of exception to the faithfulness to the "no more taxes' rule. Beyond the low-profile measure of de-indexing the tax scale, which automatically increased contribution rates for taxpayers whose incomes had grown, another tactic was also employed to minimize the political cost of tax measures. This consisted in a multiplicity of 'micro-duties', taxes characterized by their indirectness, their low yield and their potentially positive impact on the regulation of individual behaviour (for instance, the increase in duties on fizzy drinks and beer), which minimized their electoral cost and the associated social backlash.

Headline tax and matching the fiscal timetable to the electoral cycle. A final series of measures - tax hikes - were introduced during the last month of the mandate, with the aim of matching the fiscal timetable to the electoral cycle in order to rally the French around a re-burnished image of the president. The first headline measure was the creation of an 'exceptional tax on very high earnings', adopted in the 2012 Finance Bill, which ran counter to the measures taken in favour of the well-off at the beginning of the presidency. Adopted against the background of the electoral campaign, the measure was intended to be 'reparatory' and to erase the stigma (the 'president of the rich') attached to Sarkozy's initial tax policy (the loi TEPA and the tax shield). The top income tax rate was increased by one point, capital gains tax on real estate by three points and tax on capital gains and dividends by one point. A third type of headline tax hike, the rise in value-added tax (VAT) rates, was also agreed under the 2012 Finance Bill. The desirability of its adoption had been debated on numerous occasions, notably, between the two rounds of the 2007 legislative elections, but rejected because of its political costs. Initially conceived as a revenue-neutral reform, intended to bring about a 'fiscal devaluation' through the shift from social contributions to VAT, it was resurrected in the form of a revenueraising measure. The rise in the standard rate of VAT from $19.6 \%$ to $21.2 \%$ and the two point hike in social contributions on financial earnings from $13.5 \%$ to $15.5 \%$ were expected to generate more than $€ 13$ billion in revenue and to offset an equivalent reduction in the level of employers' contributions, a measure introduced to stimulate employment.

Ultimately, since the presidential elections were to be held in May 2012, the introduction of the VAT increase was deferred to 1 October 2012 and the hike in 
income-related tax contribution (CSG) to 1 July 2012. The timing of the adoption of these measures (approved in the first Amended Finance Bill for 2012 on 14 March 2012) ${ }^{7}$ was intended to enable the president to reap the political rewards from them without immediately having to bear the cost.

\section{The consolidation strategy under multiple influences: The importance of blame-avoidance strategies}

In order to understand the content and design of the consolidation policy conducted in France, we take into account the overlap between economic and administrative viabilities, international interdependencies, and blame-avoidance strategies.

\section{The formulation of an economic and budgetary response: Viabilities and international constraints}

Our exploration of the decision-making process at work in retrenchment policy has shown the importance of the nature of the stimuli and the magnitude of the crisis signals experienced, perceived and interpreted by the decision-makers in a context of great interdependencies between the countries.

The pros of being 'one of the cleanest dirty shirts in the Eurozone'. The characteristics of France's economy, with the highest level of public spending as a proportion of GDP $(56 \%)$ and the biggest balance-of-trade deficit in the Eurozone, tempered the impact of the 2008 crisis and did not prompt any drastic questioning of budgetary policy.

Less dependent on global trade, the dip in GDP was much less marked in France than in other countries. Whereas some countries were used to running budget surpluses and suddenly had to deal with substantial deficits, France's finances had been in disrepair before the 2008 crisis. At the heart of the crisis, therefore, the change appeared less sudden: the overall government deficit increased only slightly in 2009 and 2010, largely sustained by the operation of the big automatic stabilizers.

The bail-out plan for the French banks used less public money than in some other countries since state action was essentially limited to providing a guarantee to enable the banks to borrow (Cour des comptes, 2013: 155-190). The bail-out plan even generated additional state revenues from 2009 onwards.

The scale of variation in the economic and budgetary situation was smaller in France than in many other EU countries. France's political decision-makers were even less inclined to dramatize the situation in that they had four further reasons for continued confidence. First, the international markets remained confident and did not seem alarmed by the continuing widening in France's trade deficit since 2001 and the steady increase in the country's public debt since the late 1970s. Second, French debt was characterized by a high degree of liquidity: it was very 
easy to buy or sell French government bonds. For this reason, France was considered as the 'second-best choice' in the Eurozone, behind Germany. Third, despite its negative impact on the public finances and growth, population ageing in France was less marked than in other countries. With less exposure to future demographic shock (European Commission, 2012: 35), France's leaders did not feel the same degree of urgency about undertaking large-scale consolidation. In fact, these three factors combined to legitimize the choice of gradual, low-key efforts without radical structural reform. Last, but not least, France continued to receive the same AAA rating as Germany until 1 January 2012. The deterioration in France's credit began late, on 13 January 2012, with the decision of Standard \& Poor's agency to withdraw the country's AAA rating.

However, France also benefited directly from the collapse of the economies of many Southern European countries. The acuteness of the sovereign debt crisis in its Southern neighbours led the financial markets to look more favourably on France's circumstances. In the words of a popular rating agency joke, France continued to be seen as 'one of the cleanest dirty shirts in the Eurozone'. The positive attitude of the rating agencies was probably self-fulfilling: while French ratings remained excellent, French interests rates were held down, which relieved the government of the need to undertake rapid consolidation. Against a background of sovereign debt crisis marked by a sharp rise in the perceived risks of the debts of Southern European countries and by a massive withdrawal of capital from those countries, France looked like an attractive investment target. The simultaneous and global nature of the crisis in other countries reduced the cost of the debt burden on the French state, despite the very fast increase of its debt stocks.

The cons of being 'one of the cleanest dirty shirts in the Eurozone'. Nonetheless, officials in the Finance Ministry and politicians could clearly see that while France was better off than the Southern European countries, the comparison with Germany became negative from 2009. France was hit hard by the sovereign debt crisis in 2011, with a $14 \%$ increase in debt-servicing costs (see Table 2), exacerbating the risk of a budget failure.

Bond yield spreads compared with Germany showed their first clear divergence in 2009 before peaking at $1.5 \%$ in mid-2011. As one of the players belonging to the Treasury Department recalls:

even though in reality it was nothing like as bad as what was happening in Spain or in Greece, the markets sent a signal with the spread differential Germany was paying.... For political reasons, France had to remain at the controls with Germany, and Sarkozy was obsessed with parity with Germany.... He wanted France to remain in the co-pilot's seat in the management of the crisis.

A budget risk together with the risk of a loss of political credit prompted the executive to adopt more drastic retrenchment measures than it had previously implemented. That is why the second planning act for 2011-2014 marked a clear 
Table 2. Evolution of the debt service costs in France since 2007 (in millions of euros).

\begin{tabular}{llllllllll}
\hline & 2007 & 2008 & 2009 & 2010 & 2011 & 2012 & 2013 & $\begin{array}{l}2014 \\
(\text { LFI) }\end{array}$ & $\begin{array}{l}2014 \\
\text { (PLFR) }\end{array}$ \\
\hline $\begin{array}{l}\text { Total debt - } \\
\quad \text { excluding swaps }\end{array}$ & 39,550 & 44,464 & 37,625 & 40,503 & 46,256 & 46,303 & 44,886 & 46,654 & 44,854 \\
\begin{tabular}{l} 
Trend $n+1$ \\
\hline
\end{tabular} & - & $+12 \%$ & $-15 \%$ & $+7 \%$ & $+14 \%$ & $0 \%$ & $-3 \%$ & $+4 \%$ & $0 \%$ \\
\hline
\end{tabular}

Notes: LFI - Initial Budget Bill; PLFR - Amending Draft Budget Bill.

change in budgetary policy, with the objective of containing public spending growth at an average of $0.8 \%$ over the period (excluding the stimulus package). The credibility of the classical argument advanced by budget mandarins, stressing the possibility of a 'budgetary accident', received a strong boost with the Greek crisis and was reinforced in July 2011 by the spread of the sovereign debt crisis to Italy (France being perceived as the next domino likely to fall after Italy).

The main constraint on France came from Germany's demands at the time of the adoption of the European Financial Stability Facility in 2010 and the European Stability Mechanism in 2012. The solutions devised to tackle the euro crisis reinforced the centralization of decision-making power to the European level. When EU mechanisms were adopted to rescue countries with fast-rising interest rates, the contributing countries obtained the adoption of rules preventing 'excessive public deficits' and institutional mechanisms designed to prevent further crises. The Fiscal Compact and the Treaty on Stability, Coordination and Governance of 2 March 2012 forced member states to transpose the 'balanced budget rule' into their national legal systems through restrictive provisions. By laying down the principle of budget balance or surplus in public administrations and by setting a $0.5 \%$ ceiling on the permitted structural deficit (adjusted to take account of economic variations) as the 'medium-term objective' that every country had to meet, the European treaties strengthened controls over the behaviour of national politicians and diminished their discretionary powers for the future. The solidarity mechanisms came at the price of increased European central control over national budgetary policies.

However, France only partly played the game, giving the High Council of Public Finances a narrower remit than that assigned to most of its counterparts (PisaniFerry, 2014: 118). France's influence enabled it to manipulate the European rules in its favour in order to soften the fiscal discipline advocated by Germany and to avoid excessive policy restrictions (for a view on this repeated strategy, see Howarth, 2007). As Clift (2013: 22) observed:

the structural balance target differs in important respects from the public deficit in the Maastricht sense in taking more account of the economic cycle and - in theory at least - allowing for counter-cyclical fiscal policy .... The way fiscal rules are incorporated into the Fiscal Compact might seem to reflect a more 'French' than 'German' understanding of fiscal policy, economic activity and growth.... The focus on structural, as opposed to cyclical components of budget deficits within the new EU and 
National frameworks means that how potential growth rates and output gaps are defined are now of first order political significance.

According to some economists, these rules led to an underestimation of the output gap, the scale of the structural deficit and the extent of the public spending cuts required (Artus, 2013).

\section{Concentration of political power as a two-edged sword in a context of political polarization}

Our description of the decision-making process challenges the usual political science assumption that unitary states with single-party governments in semi-presidential regimes are more capable of taking swift and drastic decisions (Elgie and McMenamin, 2008) and supports explanations in terms of the concentration of blame. By concentrating power, the Fifth Republic's institutional model also concentrates responsibilities and therefore, paradoxically, encourages a flight from responsibility when difficult or electorally expensive decisions have to be taken (Pierson, 1994). From that point of view, our findings are in line with models which predict that increasing political polarization increases debt accumulation (Alesina and Tabellini, 1990; Alt and Lassen, 2006).

The first illustration is that political advocacy of retrenchment policies is considered very costly in the French system. In 2007, when the five-year term began with a relaxation of budgetary constraints (Clift, 2012a), Prime Minister Fillon's speech, in which he declared that he was in charge of a 'bankrupt state', was disowned by the president. Later, in 2009, far from taking advantage of the crisis to justify a liberal policy of retrenchment, in keeping with his personal preferences, President Sarkozy instead adopted the role of resolute defender of the French welfare state model, deliberately playing up the contrast between himself and leaders of countries forced into austerity measures. This posture as guarantor of the French welfare model was in tune with opinion polls. President Sarkozy firmly believed that he would be punished by the electorate if he decided to implement a drastic fiscal adjustment.

The second illustration is the influence of the electoral cycle on the fiscal timetable. To a significant degree, the electoral time frames were unfavourable to French government action on both the upstream and downstream sides. On the upstream side, the crisis hit in 2008 when President Sarkozy had already put together and launched his main reforms. The result was a significant level of policy dependency that prevented the government modifying its initial formulation, especially as the initial RGPP included the objective of deficit-cutting. On the downstream side, with a mandate set to end in May 2012, the electoral timetable gave the executive no incentive to adopt drastic consolidation measures immediately after the recovery plan. The importance of the electoral cycle explains why the implementation of many consolidation measures was postponed until after the 2012 elections. Whoever was in power after this would be responsible for implementing the most 
important consolidation measures. From March 2010 onwards, the apparent international consensus in favour of the adoption of stimulus measures was clearly fading, with the emergence of the sovereign debt crisis revealed by Greece's situation. The onset of the pre-electoral phase increased the risk of electoral punishment associated with retrenchment measures, and conversely constituted an incentive to deferring the budget adjustments until after the election. Caught between the risk of losing its AAA credit rating - which would demand the adoption of strong revenue and spending measures - and an electoral timetable that gave it no incentive for immediate action, the government sought primarily to manage these tensions by intensifying its use of decrementally applied 'low-profile' instruments. The government resorted to the well-tried technique of formulating its budget strategy around growth estimates grounded in deliberately optimistic hypotheses and chronic underbudgeting for certain lines (OECD, 2011).

\section{Conclusion}

What has happened since the elections of May 2012 can be seen as a confirmation of the diagnosis reached on the difficulties of the French executive - whether headed by a president of the Right or the Left - in achieving sustainable public finances. The scale of the fiscal consolidation measures adopted after the presidential elections first showed more obviously the extent to which budgetary adjustment had been deferred during the previous phase. Despite the campaign promises made by François Hollande, such as the repeal of measures like the VAT increase, the executive had no choice but to ratify and even reinforce the fiscal measures previously introduced. The effects have been recessionary. Due to the tendency to the concentration of power specific to the Fifth Republic, as outlined earlier, the president is seen as accountable for this cutback policy and is facing a dip in political and social support, as well as ever-growing corporatist opposition, linked both to its fiscal policy and to its attempts to liberalize certain economic sectors.

\section{Acknowledgment}

The authors would like to thank the reviewers of the IRAS for their very helpful comments as well as Pepper Culpepper for his insightful remarks on a previous version of this article. We also thank Vanessa Albert for her research assistance in this project.

\section{Funding}

The research leading to these results has received funding from the European Community's Seventh Framework Programme under grant agreement No. 266887 (Project COCOPS), Socio-economic Sciences \& Humanities.

\section{Notes}

1. This policy was extended and reinforced following the crisis, with 150,000 public service jobs being eliminated between 2008 and 2012 (IGA et al., 2012). 
2. The balance of trade, in continuous decline since the creation of the Eurozone because of a lack of competitiveness in the non-military industrial sectors, turned negative in 2003, switching directly from +0.6 to -4 billion euros. In 2007, the trade deficit rose to $€ 53$ billion, even before the start of the crisis.

3. French public spending grew faster than GDP: over the period 2004-2008, the gap between France's and Germany's public debt-to-GDP ratios was five points.

4. Quoted in Le Figaro, 2 July 2010.

5. French pensions accounted for $13.3 \%$ of GDP in 2009, the highest rate among Organisation for Economic Co-operation and Development (OECD) countries, just behind Italy (before its reforms). The 2010 reform in France provided for a gradual increase in the minimum pension age from 60 to 62 by 2017, depending on the year of birth, and an increase in the full pension age from 65 to 67 between 2016 and 2022. The contribution rates of civil servants would rise gradually from $7.85 \%$ to $10.55 \%$ by 2020 .

6. Health insurance spending in the basic social security systems accounted for $16 \%$ of total public spending in 2010 , that is, $9 \%$ of GDP.

7. The decree implementing the increase in the VAT rate was published in the Official Journal the same day as the second round of the presidential election.

\section{References}

Alesina A and Tabellini G (1990) A positive theory of budget deficits and government debt. Review of Economic Studies 57: 403-414.

Alt $\mathbf{J}$ and Lassen D (2006) Fiscal transparency, political parties, and debt in OECD countries. European Economic Review 50: 1430-1439.

Artus P (2013) Flash Economie, No. 804. 12 November.

Baumgartner F, Foucault M and François A (2009) Patterns of public budgeting in the French Fifth Republic. In: Brouard S, Appleton A and Mazur A (eds) The French Fifth Republic at Fifty. Basingstoke: Palgrave MacMillan, pp. 174-190.

Bezes P (2007) The hidden politics of administrative reform. Cutting French civil service wages with a low-profile instrument. Governance 20(1): 23-56.

Bezes P (2010) Morphologie de la Révision générale des politiques publiques. Une mise en perspective historique et comparative. Revue francaise d'administration publique 4: 769-796.

Blyth M (2002) Great Transformations. Economic Ideas and Institutional Change in the Twentieth Century. Cambridge: Cambridge University Press.

Brouard S, Appleton A and Mazur A (eds) (2009) The French Fifth Republic at Fifty. Basingstoke: Palgrave MacMillan.

Cac (Collectif pour un audit citoyen de la dette) (2014) Que faire de la dette? Un audit de la dette publique de la France. Paris: Attac France.

Camdessus M (2004) Le sursaut. Vers une nouvelle croissance pour la France. Ministère de l'économie, des finances et de l'industrie. Paris: La documentation française.

Champsaur P and Cotis J-P (2010) Rapport sur la situation des finances publiques. Paris: Rapport au Président de la République.

Clift B (2012a) Les politiques économiques sous Sarkozy. In: De Maillard J and Surel Y (eds) Les politiques publiques sous Sarkozy. Paris: Presses de Sciences Po, pp. 299-320.

Clift B (2012b) Comparative capitalisms, ideational political economy and French postdirigiste responses to the global financial crisis. New Political Economy 17(5): $565-590$. 
Clift B (2013) Economic policy-making in France after the crisis. Paper prepared for The Max Planck Sciences Po Center (MaxPo) seminar series Conversations on Ökonomie, Politics and Society (COOPS).

Clift B and Ryner M (2014) Joined at the hip, but pulling apart? Franco-German relations, the Eurozone crisis and the politics of austerity. French Politics 12: 136-163.

Cour des comptes (2010) Report on the state and prospects of the public finances. Paris: Cour des comptes.

Cour des comptes (2012) Rapport public annuel. Paris: Cour des comptes.

Cour des comptes (2013) Rapport public annuel. Paris: Cour des comptes.

Cox RH (2001) The social construction of an imperative. Why welfare reform happened in Denmark and the Netherlands but not in Germany. World Politics 53: 463-498.

Direction générale du Trésor (2010) Public finance White Paper 2011-2014. 29 September.

Duverger M (1980) A new political system model: Semi-presidential government. European Journal of Political Research 8(2): 165-187.

Égert B (2012) Bringing French public debt down: The options for fiscal consolidation. Cesifo Working Paper No. 3928 (category 1: public finance), September.

Elgie R (ed.) (1999) The Semi-Presidentialism in Europe. Oxford: Oxford University Press.

Elgie R and McMenamin I (2008) Political fragmentation, fiscal deficits and political institutionalization. Public Choice 136: 255-267.

Elgie R (2013) The French Presidency. In: Cole A, Meunier S and Tiberj V (eds) Developments in French Politics 5. Basingstoke, Palgrave-Macmillan, pp. 19-34.

European Commission (2012) The 2012 ageing report: Economic and budgetary projections for the $27 \mathrm{EU}$ member states (2010-2060).

European Economy (2/2012) http://ec.europa.eu/economy_finance/publications/european_ economy/2012/pdf/ee-2012-2_en.pdf.

François B (1998) Le régime politique de la Ve République. Paris: La Découverte.

Grossman E (2009) Governments under the Fifth Republic: The changing instruments/ weapons of executive control. In: Brouard S, Appleton A and Mazur A (eds) The French Fifth Republic at Fifty. Basingstoke: Palgrave MacMillan, pp. 41-58.

Hall P (ed.) (1989) The Political Power of Economic Ideas: Keynesianism across Nations. Princeton: Princeton University Press.

Hayward J and Wright V (2002) Governing from the Centre: Core Executive Coordination in France. Oxford: Oxford University Press.

Hood C (2002) The risk game and the blame game. Government and Opposition 37(1): 15-37.

Howarth D (2007) Making and breaking the rules: French policy on EU economic governance. Journal of European Public Policy 14(7): 1061-1078.

Huber JH (1996) Rationalizing Parliament. Legislative Institutions and Party Politics in France. Cambridge: Cambridge University Press.

IGA (Inspection générale de l'Administration), IGAS (Inspection générale des Affaires sociales), IGF (Inspection générale des Finances) (2012) Bilan de la RGPP et conditions de réussite de la nouvelle réforme de l'Etat. Paris, La documentation française.

Kickert W (2012) State responses to the fiscal crisis in Britain, Germany and the Netherlands. Public Management Review 14(3): 299-309.

Le Lidec P (2011) La décentralisation, la structure du financement et les jeux de transfert de l'impopularité en France. In: Bezes P and Siné A (eds) Gouverner (par) les finances publiques. Paris: Presses de Sciences Po, pp. 149-192.

Lindbom A (2007) Obfuscating retrenchment: Swedish welfare policy in the 1990s. Journal of Public Policy 27(2): 129-150. 
OECD (2011) Études économiques de l'OCDE : France 2011, Éditions OCDE.

OECD (2013) Pensions at a Glance 2013: OECD and G20 Indicators. Paris: OECD Publishing.

Pal L and Weaver K (2003) The Government Taketh Away. The Politics of Pain in the United States and Canada. Washington, DC: Georgetown University Press.

Pébereau M (2005) Rompre avec la facilité de la dette publique. Paris: La documentation française.

Pierson P (1994) Dismantling the Welfare State? Reagan, Thatcher, and the Politics of Retrenchment. Cambridge: Cambridge University Press.

Pierson P (2001) Coping with permanent austerity. Welfare state restructuring in affluent democracies. In: Pierson P (ed.) The New Politics of the Welfare State. New York, NY: Oxford University Press, pp. 410-456.

Pisani-Ferry J (ed.) (2014) Quelle France dans dix ans? Les chantiers de la decennia. Paris: France Stratégie.

Schick A (1991) Governments versus budget deficits. In: Weaver K and Rockman B (eds) Do Institutions Matter? New York, NY: Brookings Institution, pp. 187-236.

Siné A (2006) L'Ordre budgétaire. L'économie politique des dépenses de l'État. Paris: Economica.

Starke P (2006) The politics of welfare state retrenchment. A literature review. Social Policy and Administration 40(1): 104-120.

Streeck W and Mertens D (2013) Public finances and the decline of state capacity in democratic capitalism. In: Streeck W and Schäfer A (eds) Politics in the Age of Austerity. Cambridge \& Malden: Polity Press, pp. 26-58.

Vail M (2014) Varieties of liberalism: Keynesianism responses to the Great Recession in France and Germany. Governance 27(1): 63-85.

Weaver K (1986) The politics of blame-avoidance. The Journal of Public Policy 6: 371-398. Wildavsky A (1975) Budgeting. A Comparative Theory of Budgetary Processes. Boston, MA: Little Brown.

Philippe Bezes is Centre National de la Recherche Scientifique (CNRS) Research Professor in Political Science at the Centre d'Études et de Recherches de Sciences Administratives et Politiques (CERSA), France. His academic interests are administrative reforms and bureaucracies in France and in comparative perspective, state restructuring, institutional change and public policy. He is preparing a co-edited volume (with Steven van de Walle, Gerhard Hammerschmid and Rhys Andrews) entitled Public Administration Reforms in Europe: The View from the Top (Edward Elgar, forthcoming in 2015) from the European project COCOPS (Coordinating for Cohesion in the Public Sector of the Future) examining the effects of New Public Management (NPM) reforms in European countries.

Patrick Le Lidec is a political scientist and senior Centre National de la Recherche Scientifique (CNRS) Research Fellow at the Center for European Studies at Sciences Po, France. His main research interests are decentralization policies, local government reforms and territorial restructuring in comparative perspective, including such items as national trajectories of territorial reforms, multi-level and metropolitan governance, the sociology of public finance, and the sociology of political work. He recently published 'Decentralisation and territorial reforms in 
France: How constitutional constraints impact strategies for reform', in Arthur Benz and Felix Knüpling (eds) Changing Federal Constitutions. Lessons from International Comparison (Opladen: Verlag Barbara Budrich, 2012) and co-edited (with Didier Demazière) Les mondes du travail politique: Les élus et leurs entourages (Presses universitaires de Rennes, 2014). 